Journal of Social Sciences 8 (3): 454-458, 2012

ISSN 1549-3652

(C) 2012 Science Publications

\title{
Level of Water Awareness at Some Jordanian Universities Student's
}

\author{
Mohamad Said Damanhouri, \\ Bashar Abdallah Al-Saleem and Yousra Yousef AL-Ali \\ Department of Administrative and Financail Sciences, \\ Prince's Alia College, Al-Balqa' Applied University, Po. Box 941941, Amman 11194, Jordan
}

\begin{abstract}
Problem statement: Jordan has been facing shortage in water sector during the last three decades due to natural and society factors, weakness of water awareness is one of these Society factors, so this study focused on the level of water awareness in fields of; water significant in life, water problem in Jordan, water conservation at part of Jordanian society. Approach: The study aimed to Investigate how some Jordanian Universities students behave to identify the level of water awareness in sectors of water, giving students positive attitudes towards water resources and conservation, uses and reduce consumption. Encourage students for voluntary collective actions as A hope to raising water awareness. The society sample study were represented by (320) Jordanian Universities students, take in consideration the following variables: Academic specialists, sex, University status and average monthly income per family. Data base for previous variables obtained by special questioner prepared for this study. Data run to statistical analysis through some simple Descriptive statistical approaches as (ANOVA). Results: The study showed that the level of water awareness towards water significant at a weak level, it reached to $(57 \%)$ of sample study towards water conservation. Students of scientific specializes have water awareness more than humanitarian specializes. There isn't impact of University status and average monthly income on the level of water awareness. Conclusion/Recommendations: Most of study sample recognized with significant of water at life, they admit that Jordan faced water problem, but female were more than male at the level of water awarenes, also scientific specialists more than humanitarian specialties. Study recommends to enrich the curriculum of humanitarian sciences, with more topics looking for water and encourage personal activities and volunteers work to conserve water and rationalized it, also activation laws and legislation related with water.
\end{abstract}

Key words: Water awareness, universities students, water significant, water shortage, water conservation, Jordanian Universities Students, University status

\section{INTRODUCTION}

Water is the elixir of life and the Original of flourishing human civilization and urbanization. throughout history, managing the water affairs has always been the driving force towards establishment of great Nation. Throughout the world countries are concerned with the effects of unclean drinking water, so such water born diseases which are a major cause of morbidity and mortality. Water resources in Jordan are critically limited and the problem of water scarcity and quality represent a challenge for decision makers. This is due to fluctuation in rain fall, increasing population growth, extension of urbanization, effect of global warming and unrationalized used of water wit refer to the weakness level of water awareness. Water awareness necessitates stringthen management to be achieved. The keystone of this awareness is the willing for popular participation in water planning;conceptualization and implementation. Water awareness care with many issues of water such as it's resources, conservation, consumption, management harvesting, pollution, water crises and water policies. Promote water awareness programs and activate the role of civil society including students, children, youth, women, farmers, religion men and all slides of society. Water awareness issues isn't a goal in it self, but a means to achieve integrated water resources

Corresponding Author: Mohammad Said Damanhouri, Department of Administrative and Financial Sciences, Prince's Alia College, Al-Balqa' Applied University, Po. Box 941941, Amman 11194, Jordan 


\section{J. Social Sci., 8 (3): 454-458, 2012}

management. Water awareness is defined as the person's realization of water issue as an environmental problem from the following prospective-size; causes; and it's different domains. The researchers tend to defined water awareness, as the one's encompass of current as well as future of his water recourses, with respect to water quality and quantity as well, which shall enable him to use it with maximum benefit, minimum cost and for longest time possible to acquire the capability of positive contribution towards protection it from potential and threats.

\section{MATRIALS AND METHODS}

Many Studies discussed some aspects of Water awareness such as-(Damanhouri, 2010; Dan'azumi et al., 2010) that study discuses the effect of raising the environmental awareness on reducing kitchen water, the result showed that the average consumption of kitchen water was 59/L/day/family, reduced after raising environmental awareness to $49.5 \mathrm{~L} /$ day/family, with an average of $9.5 \mathrm{~L} /$ day/ /family, which is very vital indicator. Anderson (2010) discussed unclean drinking water and concluded that the household don't have alternatives for water treatment; only $19 \%$ of them treated drinking water used the following means:-boiling $51.3 \%$,chemical treatment $42.3 \%$, filtering $6.1 \%$, others $3 \%$. The study also showed that boiling unclean drinking water needs more amount of water, increased more consumption of foul, requires additional household labor and chemical treatment was more desirable, it's coasted more money in situation where households were very poor. Maio et al. (2010) Studied water resources of domestic water for household in ado-kite and concluded that 59\% of them depended on wells, nevertheless, $84 \%$ had access to improve sources, only $10 \%$ obtained supplies from pipe water in spite of piped network spread wide restricted to the city core. Variables affected on improved water sources were:-Distance, time, trip numbers and adequancy of supplies places limitation on access to improve sources (Shahateet, 2008). Revealed on economic approach to reduce water problems in Jordan, take in consideration following variables:-Increasing population size, declining rainfall, increasing demand of water, deeping shortage of supply, agricultures and industrial production, price of unite exports, lack of financial resources. This study attempt to identify the level of water awareness in fields of: Water significant in life, water problem deficit in Jordan, water conservation (quality and quantity), among some students at Jordanian universities. This study also seeks to know about each of human perception, respond, adjustment and adaptation towards water shortage problem.
Table 1: Descriptive of sample study and variables study

\begin{tabular}{|c|c|c|c|}
\hline \multicolumn{2}{|c|}{-------Variables of study------- } & Frequency & $(\%)$ \\
\hline \multirow{2}{*}{ University status } & Public & 200 & 62.50 \\
\hline & Private & 120 & 37.50 \\
\hline \multirow{2}{*}{$\begin{array}{l}\text { Academic } \\
\text { specialize }\end{array}$} & Scientific & 170 & 53.00 \\
\hline & Humanity & 150 & 47.00 \\
\hline \multirow[t]{2}{*}{ Sex } & Male & 140 & 43.70 \\
\hline & Female & 180 & 56.30 \\
\hline Average of & $>500 \mathrm{JD}$ & 174 & 54.40 \\
\hline monthly income & $<500 \mathrm{JD}$ & 146 & 45.60 \\
\hline
\end{tabular}

The study aims to develop students' knowledge of the current and future conditions of water and giving students positive attitudes which motivated them to rational investigated of water resources decreased of water waste and conservation it of pollution. As well as broaden the base of voluntary collective action, through Participation in environmental programs and activities, especially those related to water resources and their use. society of study sample was represented by (320) Jordanian universities students, take in consideration the following variables:Academic Specializes, Sex, Universities Status, Monthly income average per family (Table 1), Special questioneer involved previous variables was prepared for the study, Data base was obtain from the questioneer, data run in to Statistical analyzed through some descriptive statistical approach as (ANOVA).

\section{RESULTS AND DISCUSSION}

Level of water awareness in field of significant of water at life: Statistical analysis showed, that the level of water awareness at community study sample is a weak level, it reaches for who have an Awareness about this object $57 \%$, although $95 \%$ of them recognize that water consider creation material and the basis of life. And $88 \%$ of respondents admit that religion urges to conserve water for it's importance in life, $85 \%$ emphasize on importance of water for human health, animal and plant. But in contrast, $42 \%$ of them only agree on importance of water in urban development and civilization, while the level of water awareness about the importance of water in sectors of agriculture, industry, transport and tourism has emerged in a row in the following percentage: (58, 55, 45 and 56\%), in addition $38 \%$ of them believe there is relation between water needs and some regional and international conflicts, only $28 \%$ assert that water is a key component for food and national security. this weakness in level of water awareness about the importance of water, refer to considered water is not of cultural topics of initial youths concerns, as their interest in information technology, sports and other issues, also the curriculum and courses academic of humanity disciplines are poor for as much as enough of the topics that appear the importance of water in life. 


\section{J. Social Sci., 8 (3): 454-458, 2012}

Table 2:Variables showed with differences statistical significant $(\alpha=$ $0.05)$

\begin{tabular}{|c|c|c|c|c|}
\hline $\begin{array}{l}\text { Some sectors of } \\
\text { water awareness } \\
\text { deal in the study }\end{array}$ & \multicolumn{2}{|c|}{ Variables of the study } & $\begin{array}{l}\text { Arithmetic } \\
\text { mean }\end{array}$ & $\begin{array}{l}\text { Statistical } \\
\text { significant }\end{array}$ \\
\hline $\begin{array}{l}\text { Significant of } \\
\text { water }\end{array}$ & $\begin{array}{l}\text { Academic } \\
\text { specialize }\end{array}$ & $\begin{array}{l}\text { Scientific } \\
\text { humanity }\end{array}$ & $\begin{array}{l}0.94 \\
0.80\end{array}$ & 0.005 \\
\hline $\begin{array}{l}\text { Water problem } \\
\text { in Jordan }\end{array}$ & $\begin{array}{l}\text { Academic } \\
\text { specialize }\end{array}$ & $\begin{array}{l}\text { Scientific } \\
\text { humanity }\end{array}$ & $\begin{array}{l}0.33 \\
0.30\end{array}$ & 0.023 \\
\hline & Sex & $\begin{array}{l}\text { Male } \\
\text { Female }\end{array}$ & $\begin{array}{l}0.30 \\
0.33\end{array}$ & 0.044 \\
\hline $\begin{array}{l}\text { Water } \\
\text { conservation }\end{array}$ & Sex & $\begin{array}{l}\text { Male } \\
\text { Female }\end{array}$ & $\begin{array}{l}0.60 \\
0.68\end{array}$ & 0.001 \\
\hline
\end{tabular}

Analysis of Variance (ANOVA) in the (Table 2) has been showed the existence of statistically significant differences $(\alpha=0.05)$ due to the impact of academic specialization in the level of water awareness about the importance of water in life, for the benefit of scientific disciplines, this is refer to that the academic courses for people with scientific specialties include a variety topics around water which is not available at Sufficient degree courses in humanitarian disciplines, were the arithmetic average of the scientific specialization (0.80), Also, students of scientific disciplines dealing with water constantly over the students of Humanitarian Specialties, through laboratory and field activities related for their specialties, data analysis showed there is not differences statistically significant due to the effect of sex in the level of water awareness of the importance of water in life, as both sex consider water is essential of life and can' t be dispensed with else. As well as was the case for the status of the University (Public, Private) didn't show differences statistically significant due to the impact of University (Public, Private) in water awareness about the importance of water in life, this explained by the fact that the courses of the academy on the subject of water are similar to a large degree, because all subject were adoption by ministry of higher education in Jordan. Data Analysis didn't appear differences with statistically significant due to the impact of monthly income average per family in level of water awareness towards the importance of water in life, this due to consider water necessary for every person, he can't do and live without it, whether he was rich or poor, but may different in obtained it in form qualitative or quantitative.

The level of water awareness in field of water problem in Jordan: Although of the weakness level of water awareness of the community study sample on the importance of water in life, which showed earlier, the results of statistical analysis showed that $63 \%$ of study sample admit that Jordan suffers from a severe shortage of water needs, also $90 \%$ of them expressing their discontent of water rank supply for homes, with an average day in a week, more clearly 57\% of respondents said that water does not reach the tanks on roofs of their homes, because of weakness in pumping in order to reduce water consumption, According to the specific water policies. When they exchanges on the reasons for the problem, $78 \%$ of them was attributed this problem to the high population growth in Jordan,as result of migrations from rural to urban centers and from regional countries, which causes lack of water consumption and failure to conserve water quality of water sources, which are all very limited by virtue of Jordan geographical nature, as the most of its territory lies within the area rid and semi-rid lands, addition to the incidence in a continental away from seas and Solitude of the rivers, exception of the Jordan River with very small balance of water compared to other rivers. So $42 \%$ of study sample believe that the scarcity of water resources contribute at this problem, also $25 \%$ only believe that the contamination of water sources makes it unfit for use, this removed it out of accounts of water budget in Jordan. and According to opinion of $73 \%$ of them,they Suggested to alleviate this problem through Co-operation of government efforts, popular organizations, non-governmental organizations and citizens, $67 \%$ of them encourage harvesting water, especially at the level of construction in domestic rainwater and used it in a bathroom, home garden irrigation and car washing, which contributes to alleviate the water deficit of water balance in Jordan, while $85 \%$ of them supported to prevent the use of drinking water in building and construction and $81 \%$ admit the ineffectiveness of laws and legislations of water management to reduce water consumption and loses water. Analysis of Variance (ANOVA) has emerged Statistically Significant differences $(\alpha=0.05)$ due to the impact of academic specialize towards water problem and for the benefit of Scientific disciplines, so as these disciplines interested in a degree more of disciplines humanitarian with water through a curriculum planned and fields of scientific research, making them more feel with the problem, so Arithmetic mean hear was $(0.33)$ while to humanitarian disciplines it's reached (0.30) Table 2. Data analysis showed differences statistically significant $(\alpha=0.05)$ for the impact of sex in the level of awareness about the problem of water shortage in Jordan and in favor of females as the arithmetic average $(0.33)$ for females and (0.30) for males (Table 2), this is due to that any failure to provide the needs of water especially in the household uses more raises disturbing than males, as they are assigned to them matters of hygiene and food 


\section{J. Social Sci., 8 (3): 454-458, 2012}

preparation and washing and cleaning kitchen at the house. Statistical analysis did not show differences statistically significant due to the impact of University status (public, private) in awareness towards water problem; this is for the same reasons that did not show the differences in case of the impact of University status on level of water awareness about the importance water in life, as referred earlier. Also data analysis did not show statistically significant differences due to impact of monthly income average in the awareness of water problem, because rare of wate getup human feels, weather he was rich or poor, that he couldn't live without water, regardless of the level of monthly income.

Level of water awareness in field of water conservation: Problem of water shortage, which expressed by population study, about level of water awareness toward water problem in Jordan, require increased interest in conservation water, both quantity and quality. But it is shown by statistical analysis of data study, that the level of awareness toward water conservation very weak, it does not exceed $31 \%$ of Study sample, although $63 \%$ of them admit to the problem of water shortage in Jordan. In spite of that $72 \%$ of them wash their cars with water used for domestic purposes and $67 \%$ resort to irrigate their home gardens of this water. Also not keen to eat meals in a collective (family) to reduce water consumption for cleaning three meals tools, as the percentage of interest in this behavior was $31 \%$, note that it is possible by means of an initial simple, like the status of a bottle filled with water and put it in Niagara's bath for example, or washing the car with water bucket, or irrigation home gardens by washing water, these means reduce the amount of water consumption for domestic purposes. Also whose keen on recycling household water use does not exceed $18 \%$, that who care to prevent leakage of the internal network of water did not exceed $31 \%$ generally the level of water awareness in the field of water conservation and in quantitative terms was $35 \%$ and the level of water awareness in water conservation in terms of quality was less than the level of awareness in terms of quantitative, it's reached to $27.5 \%$ of society study, while only $15 \%$ understand the concept of water pollution and $28 \%$ only have knowledge about water sources, also only $32 \%$ of them interest in cleaning water tanks at their homes. Data Analysis of Variance (ANOVA) to the existence of differences Statistically Significant $(\alpha=0.05)$ due to the effect of sex in level of awareness toward water conservation in Jordan came differences in favor of females as the arithmetic average here reached to (0.68) while in case of males it reached (0.60) (Table 2), due to the multiplicity of homework-related uses of water and required of females and males is not required. While it does not show statistically significant differences of impact of University status (Public, Private) at the level of water awareness in water conservation sector, this may be due to the similarity of academic courses that deal with water in all Universities. Also it doesn't show statistically significant differences of impact of academic specialization and the level of monthly income-on level of water awareness about water conservation.

\section{This study found out the following results:}

- The Study indicates that the level of water awareness about water significant in life is A weakness level, as the percentage of their awareness of this attitude reached to $57 \%$ of study sample

- The study showed that the level of water awareness toward water conservation in both quantity and quality is very weak, since found out, that they have an awareness in this field doesn't exceed $35 \%$ of study sample

- The study found that females feel with problem of water shortage in Jordan more than Males. As well as scientific disciplines students feel with problem of water shortage is more than students of humanitarian specialties

- There isn't statistically significant impact of University Status (Public, Private) towards the level of water awareness, as well as a monthly income average per family

\section{CONCLUSION}

- Study concluded that the level of awareness in the field of perception and adaptation and respond to the problem of water shortage in Jordan, was un satisfaction, and towards water conservation, this referred for weakness of water awareness

- The study concluded that females are more careful in conservation of water more than males

Recommendations: The study recommends the following actions, which can contribute to raising level of water awareness:

- Enrich the curriculum Universities of humanitarian disciplines with more topics that are looking at water in terms of its significant importance, adapt and respond, water shortage, water conservation, 
both quantity and quality and rationalization of water uses

- Organized of student activities, especially male students through seminars or workshops to train students to simple means to rationalize water consumption in the household

- Laws and legislations related of water demand management, must be activated towards important of water, it's resources, uses, consumption, conservation, reducing waste water and reducing water loses

- Encourage personal or family initiatives or volunteer work, which aims to conserve water, such as water harvesting at the level of the family home, or create simple ways to rationalize water consumption

- Activating the role of media and youth associations and clubs, non-governmental associations and worships, in raising the level of water awareness and water conservation

- Encourage graduate students at universities and scientific research centers to conduct scientific researches towards topics related of water

\section{REFRENCES}

Anderson, B.A., 2010. Water pollution awareness and drinking water treatment in rural South Africa. Amman. Am. J. Applied Sci., 1123-1128. DOI: 10.3844/ajassp.2010.1123-1128

Damanhouri, 2010. Effect of raising environmental awareness on reducing kitchen water consumption by Jordanian Families living in Amman. Am. J. Applied Sci., 7: 1123-1128. DOI: 10:38.3844/ajassp.2010.1123-1128

Dan'azumi, S., S. Shamsudin and A. Aris, 2010. Modeling the distribution of rainfall intensity using hourly data. Am. J. Environ. Sci., 6: 238-243. DOI: 10.3844/ajessp.2010.238.243

Maio, M.D., F. Minucci and G. Nocerino, 2010. Evaluation of the groundwater global pollution risk: Relationships with territorial planning. Am. J. Environ. Sci., 6: 103-114. DOI: 10.3844/ajessp.2010.103.114

Shahateet, M.I., 2008. An economic model for water sector in Jordan. J. Soc. Sci., 4: 264-271. DOI: 10.3844/JSSP.2008.264-271 